\title{
Effects of Dietary Probiotic Bacillus sp. D2.2 and Prebiotic Sweet Potato Extract on Growth Performance and Resistance to Vibrio harveyi in Pacific white shrimp, Litopenaeus vannamei
}

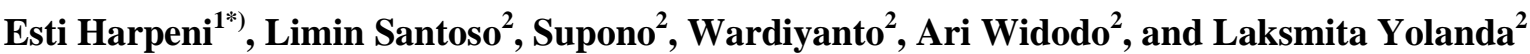 \\ ${ }^{1}$ Marine Science Study Program, University of Lampung, Bandar Lampung, Indonesia \\ ${ }^{2}$ Aquaculture Study Program, University of Lampung, Bandar Lampung, Indonesia \\ Email: esti.harpeni@fp.unila.ac.id ${ }^{*}$, limin.sentiko@gmail.com,supono_unila@yahoo.com,wardibdifp@gmail.com, \\ ariwidodo216@gmail.com,and laksmitayolanda23@gmail.com
}

\begin{abstract}
Esti Harpeni, Limin Santoso, Supono, Wardiyanto, Ari Widodo, and Laksmita Yolanda. 2017. Effects of Dietary Probiotic Bacillus sp. D2.2 and Prebiotic Sweet Potato Extract on Growth Performance and Resistance to Vibrio harveyi in Pacific Pacific white shrimp, Litopenaeus vannamei. Aquacultura Indonesiana, 18 (2): 55-61. In this study, the effects of oral administration of probiotic Bacillus sp. D2.2 and prebiotic from sweet potato extract on growth performance and resistance against Vibrio harveyi in Pacific white shrimp (Litopenaeus vannamei) were investigated. During 32-day feeding experiment, 360 individuals of Pacific white shrimp (PL15) with initial weight of $0.02 \pm 0.002 \mathrm{~g}$ were fed with basal diet as control (A); supplemented with $6 \%$ probiotic and $0 \%$ prebiotic (B); $6 \%$ probiotic and $2 \%$ prebiotic $(\mathrm{C}) ; 6 \%$ probiotic and $4 \%$ prebiotic (D). At the end of feeding trial, weight gain (WG), average daily growth (ADG), feed conversion ratio (FCR), and survival rate (SR) were assessed. WG, ADG and FCR of the shrimp were significantly better in treatment $\mathrm{D}$ than those of the shrimp in other treatments. Control and treatment D as the best feeding trial were selected for challenge test with infectious $V$. harveyi. Survival rate and mean time to death (MTD) of the shrimp fed the supplemented diet were not significantly different $(\mathrm{P}>0.05)$ to the control. Infection levels in shrimp were evaluated using morphological scoring methods. Infection levels of $V$. harveyi in shrimp fed the diet were lower compared to the control.
\end{abstract}

Keywords: Disease resistance; Growth; Prebiotic; Probiotic Bacillus sp. D2.2

\section{Introduction}

The demand for environment-friendly in shrimp culture has increased mostly due to negative side effects of antibiotic-resistant bacteria (Wright, 2010). Therefore, the use of antibiotics in aquafeed has been restricted, such as in Europe (EC Regulation 1831/2003) and USA (U.S. Food and Drug Administration, 2008). As an alternative, the uses of probiotics or prebiotics have heightened attention. Probiotic are live microbial feed supplement that contributes to intestinal microbial balance and maintains the organism's health (Soccol et al., 2010). In recent years, several researchers have demonstrated that probiotics can enhance the disease resistance of shrimp by suppressing the pathogens, enhancing immunity or improving water quality (Verschuere et al., 2000). Thus, usage of probiotics has been considered as one of the most promising preventive methods in aquaculture. Quite a few microorganisms from the genus Bacillus have been used widely as putative probiotics. Correspondingly, a number of researchers have demonstrated that Bacillus can enhance the nutritional and health benefits of shrimp (Rengpipat et al., 1998; 2000; 2003; Li et al., 2009). Bacillus sp. D2.2 that used in this experiment was non-pathogenic bacteria (Hardiyani et al., 2016) and able to inhibit the in vitro growth of Vibrio harveyi (Setyawan et al., 2014). Meanwhile, prebiotics can increase probiotics performance since prebiotics as nondigestible food ingredients benefit to selectively stimulate the growth and/or activity of bacteria in the host's intestinal tract (Gibson et al., 2004). In addition, nutritional and health benefits of prebiotics oligosaccharides have been demonstrated in shrimp (Li et al., 2007; Zhou et al., 2007; Li et al., 2009).

Findings from the latest research show that many diseases in aquatic animals are associated with the changes in intestinal microbiota (Xiong et al., 2015). One of the most promising methods for controlling shrimp diseases in aquaculture is to enhance their non-specific defense and adjust 
the structure of intestinal flora via combination of probiotic and prebiotic, such as in lobster (Daniels et al., 2010), sea cucumber (Sun et al., 2012), and shrimp (Partida-Aranguere et al., 2013). Synbiotic, a combination of probiotics and prebiotics beneficially affects the host and improves host welfare by improving the survival and colonization of live microbial dietary supplements in the gastrointestinal tract, by selectively stimulating the growth and/or by activating the metabolism of one or a limited number of health-promoting bacteria (Gibson and Roberfroid, 1995). Synbiotic has also been considered to replace antibiotic as the result of the negative effects such as the appearance of antibiotic-resistant pathogens and concerns over the dispersal of antibiotic-resistant genes brought by using antibiotic (Bengmark, 2005).

A few studies have been revealed the effects of combined supplementation of probiotic Vibrio alginolyticus SKT-b and sweet potato in enhancing the growth performance and immune response (Azhar, 2013; Oktaviana et al., 2014; Nurhayati et al., 2015). The aim of this study is to evaluate the effects of oral administration of probiotics Bacillus sp. D2.2 together with prebiotic of sweet potato extract on the growth and disease resistance of shrimp, Litopenaeus vannamei.

\section{Materials and Methods}

\section{Probiotic and prebiotic preparation}

The experiment used Bacillus sp. D2.2 as the probiotic bacteria. It was isolated from traditional tiger shrimp farm in East Lampung (Setyawan, et al., 2014). The concentration of Bacillus sp. D2.2 was approximately $10^{6}$ colonyforming unit $(\mathrm{CFU}) \mathrm{ml}^{-1}$. Probiotic bacteria was prepared by culturing on seawater complete-agar (SWC, $5 \mathrm{~g}$ bacto peptone (Oxoid), $1 \mathrm{~g}$ yeast extract (Oxoid), $3 \mathrm{ml}$ glycerol, $15 \mathrm{~g}$ bacto agar (Himedia), $750 \mathrm{ml}$ seawater, and $250 \mathrm{ml}$ distilled water) and then transferred to SWC-broth (without agar) with rotary shaker at $140 \mathrm{rpm}$ for $24 \mathrm{~h}$ at $30^{\circ} \mathrm{C}$.

Production of prebiotic was started with the production of sweet potato starch (Harpeni et al., 2016). Extraction of oligosaccharide was done by soaking the potato in boiling water. Five grams of sweet potato starch was mixed with 40 $\mathrm{ml}$ boiled water and then stirred for 10 minutes in $85 \pm 2^{\circ} \mathrm{C}$ (Sukenda et al., 2015). Two types of oligosaccharides, sucrose and raffinose, were analyzed by using High Performance Liquid Chromatography (HPLC). The concentrations were $2.59 \% \mathrm{w} / \mathrm{v}$ (sucrose) and $0.04 \% \mathrm{w} / \mathrm{v}$ (raffinose).

\section{Experimental diet preparation}

The basal diet was commercial pellets that contained approximately $30 \% \mathrm{w} / \mathrm{w}$ crude protein and $5 \% \mathrm{w} / \mathrm{w}$ crude lipid which were suitable for the growth of the shrimp. Four treatments were used as the experimental diets were: Diet A (basal diet used as the control), Diet B (basal diet supplemented with $6 \%$ probiotic Bacillus sp. D2.2 w/w), Diet C (basal diet supplemented with $2 \%$ prebiotic and $6 \%$ probiotic Bacillus sp. D2.2 $\mathrm{w} / \mathrm{w}$ ), and Diet D (basal diet supplemented with $4 \%$ prebiotic and $6 \%$ probiotic Bacillus sp. D2.2 $\mathrm{w} / \mathrm{w})$. All supplements were thoroughly mixed with $2 \%$ egg yolk as a binder (Sukenda et al., 2015). Subsequently, the pellets were air dried at room temperature and stored in the plastic bags until used.

\section{Culture condition}

This study was conducted in the Aquaculture Laboratory, Department of Fisheries and Marine Sciences, Faculty of Agriculture, University of Lampung. The experiments used Pacific white shrimp L. vannamei in post-larval stadia (PL) 15. These shrimps were obtained from a commercial hatchery in Kalianda, South Lampung. The shrimp were weighed $(0.02 \mathrm{~g} \pm$ 0.002 mean initial weight), and randomly distributed to four experimental groups, and replicated in three times. The rearing tanks were $50 \times 40 \times 40 \mathrm{~cm}$ in 40 litres of volume. Each replication contained 30 shrimp, fed on experimental diets at the dose of $8-10 \%$ body weight and reared for 32 days. Shrimp were fed to apparent satiation three times daily. Water quality during the experiment was maintained by siphoning out shrimp feces and exchanging culture media at a rate of $10 \%$ daily. Water quality during the experiment was kept at the following parameters: temperature $27-28{ }^{0} \mathrm{C}$, salinity 29-32 ppt, dissolved oxygen $>3.5 \mathrm{mg} / \mathrm{L}$, and $\mathrm{pH}$ 7.5-8.5.

\section{Growth trial parameters}

After 32 days experiment, the total numbers of shrimp were counted and weighed. Weight gain (WG), average daily growth (ADG), 
feed conversion ratio (FCR) as well as survival rate (SR) was calculated using the following equations:

WG $=($ final weight-initial weight/initial weight $)$

ADG =weight gain/days

FCR =total dry feed intake $(\mathrm{g}) /$ wet weight gain $(\mathrm{g})$ SR $=($ final number of shrimp/initial number of shrimp $) \times 100$

The test aimed to study the performance of the best experimental diet during growth trial in increasing $V$. harveyi resistance. The pure culture of Vibrio harveyi was obtained from the Fish Health Laboratory, Center for Marine Aquaculture, Lampung. Two hundred and fourty shrimps (PL 25) were distributed into two treatments (basal diet as control and treatment D as the best experimental diet) and replicate four tanks. Shrimps were reared in different tanks. All shrimps were fed for 7 days, and were then infected with $10^{6}$ colony-forming unit $(\mathrm{CFU}) / \mathrm{mL}$ of $V$. harveyi by immersion. Seven days after infection, shrimp were then observed. The resistance parameters including SR, relative percent survival/RPS (Khimmakthong et al., 2011) and mean time to death/MTD (Nitimulyo et al., 2005) were calculated.

RPS $=1-\left\{\frac{\% \text { of mortality }(\text { treated })}{\% \text { of mortality }(\text { control })}\right\} \times 100 \%$

$\operatorname{MTD}=\frac{\sum_{i=1}^{n} \mathrm{a} i \mathrm{~b} i}{\sum_{i=1}^{n} \mathrm{~b} i}$

Note: $\mathrm{a}=$ mortality time (hours)

$b=$ number of dead shrimp

The clinical signs and hepatopancreatic histological examination were also observed. Shrimps were immediately fixed in Davidson's fixative (Bell and Lightner, 1988; Joshi et al., 2014) until processing. After fixating, the tissues were embedded in paraffin wax, sectioned, stained with hematoxylin and eosin (H\&E) and then examined under light microscopy (at 400x magnification).

\section{Data analysis}

The growth trial data were analyzed using one-way ANOVA followed by LSD's multiple range test. Histological observation on the hepatopancreatic damages i.e. percentage necrosis, vacuolation and degeneration were calculated. Relative percent of survival and mean time to death were analyzed using one sample tTest (IBM SPSS version 22). Clinical signs were scored based on the infection levels of shrimp. Score 1 (light infection): lose appetite and balance, score 2 (mild infection): reddened body and tail, score 3 (heavy infection): gill damages, and score 4 (very heavy infection): hepatopancreatic damages until dead.

\section{Result}

\section{Growth performance}

The significant differences in weight gain and ADG were observed among treatments. The better percentage of prebiotic resulted in better weight gain and ADG as well as FCR. Based on growth performance, the best treatment was diet $\mathrm{D}$ and was used for the challenged test. The higher percentage of prebiotic results in the higher weight gain and ADG. Similarly, average FCR among treatments was significantly different. The higher percentage of prebiotic results in the lower FCR. The FCR of shrimp fed with Diet A (Control) was 3.70 \pm 0.40 , the highest FCR among other treatments. Survival of shrimp was high for all treatments ranging from 71 to $90 \%$. No significant difference was found between diet A (control) and diet B (supplemented with $6 \%$ probiotic and $0 \%$ prebiotic, w/w); and also between diet $\mathrm{C}$ (supplemented with $6 \%$ probiotic and $2 \%$ prebiotic, $\mathrm{w} / \mathrm{w})$ and diet $\mathrm{D}(6 \%$ probiotic and $4 \%$ prebiotic, w/w) (Table 1). Based on the growth performance, the best experimental diet was diet D (supplemented with $6 \%$ probiotic and $4 \%$ prebiotic, w/w) and used in the challenged test.

Table 1. Growth, diet utilization and survival rate of $L$. vannamei fed on different experimental diets for 32 days. Means in a column with different letters were

\begin{tabular}{ccccccc}
\hline Treatments & Initial weight $(\mathrm{g})$ & Final weight $(\mathrm{g})$ & WG $(\mathrm{g})$ & ADG $(\mathrm{mg})$ & FCR $(\%)$ & SR $(\%)$ \\
\hline A & $0.02 \pm 0.002$ & $0.52 \pm 0.07$ & $0.50 \pm 0.07^{\mathrm{a}}$ & $15.7 \pm 2.3^{\mathrm{a}}$ & $3.70 \pm 0.40^{\mathrm{a}}$ & $71.11 \pm 6.94^{\mathrm{a}}$ \\
\hline B & & $0.83 \pm 0.07$ & $0.81 \pm 0.07^{\mathrm{b}}$ & $25.4 \pm 2.2^{\mathrm{b}}$ & $2.90 \pm 0.20^{\mathrm{b}}$ & $73.33 \pm 6.67^{\mathrm{b}}$ \\
\hline C & & $1.40 \pm 0.01$ & $1.38 \pm 0.01^{\mathrm{c}}$ & $43.1 \pm 2.4^{\mathrm{c}}$ & $1.52 \pm 0.06^{\mathrm{c}}$ & $83.33 \pm 3.33^{\mathrm{c}}$ \\
\hline D & & $1.90 \pm 0.04$ & $1.88 \pm 0.04^{\mathrm{d}}$ & $58.6 \pm 1.3^{\mathrm{d}}$ & $1.12 \pm 0.04^{\mathrm{d}}$ & $90.00 \pm 3.33^{\text {cd }}$ \\
\hline
\end{tabular}




\section{Resistance Parameters}

Survival rate between control and Diet D (supplemented with $6 \%$ probiotic and $4 \%$ prebiotic) was not significantly different $(87 \pm$ 7.37and $95 \% \pm 1.96$ respectively). RPS for Diet D was $53.48 \%$. Shrimp fed with Diet A (control) had the slower average time of death compared to shrimp fed with experimental diet $(108 \pm 27.3$ and $75 \pm 35.1$ hours respectively) (Figure 1), however, MTD was not significantly different.

Numbers of shrimp suffered from various infection levels of $V$. harveyi were basically lower in shrimp fed with treatment diet. Mostly the shrimp suffered from mild infection (score 2) indicated with redness of tail (Figure 2).

After seven days of the challenged test, more than $90 \%$ shrimps indicated the prominent degenerative hepatopancreas, $36-52 \%$ of necrosis appeared in hepatocytes and $37-43 \%$ of vacuolation was noticeable. In contrast, hepatopancreas of shrimp fed with probiotic and prebiotic in diet D had less damaged than those fed with Diet A (Control) (Figure 3 and 4).

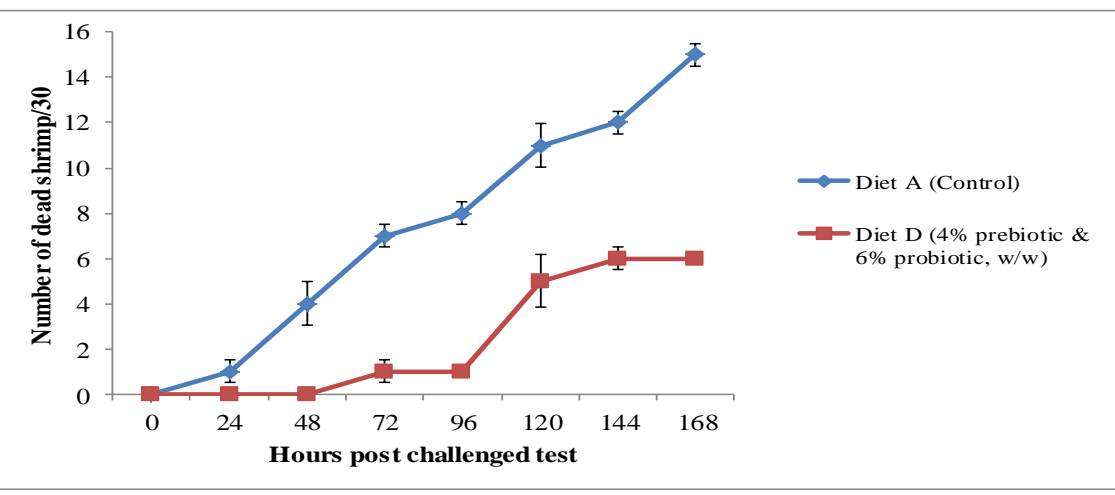

Figure 1. Mortality of shrimp after challenged test of two diets, i.e. basal diet and experimental diet (basal diet supplemented with $4 \%$ prebiotic and $6 \%$ probiotic Bacillus sp. D2.2)

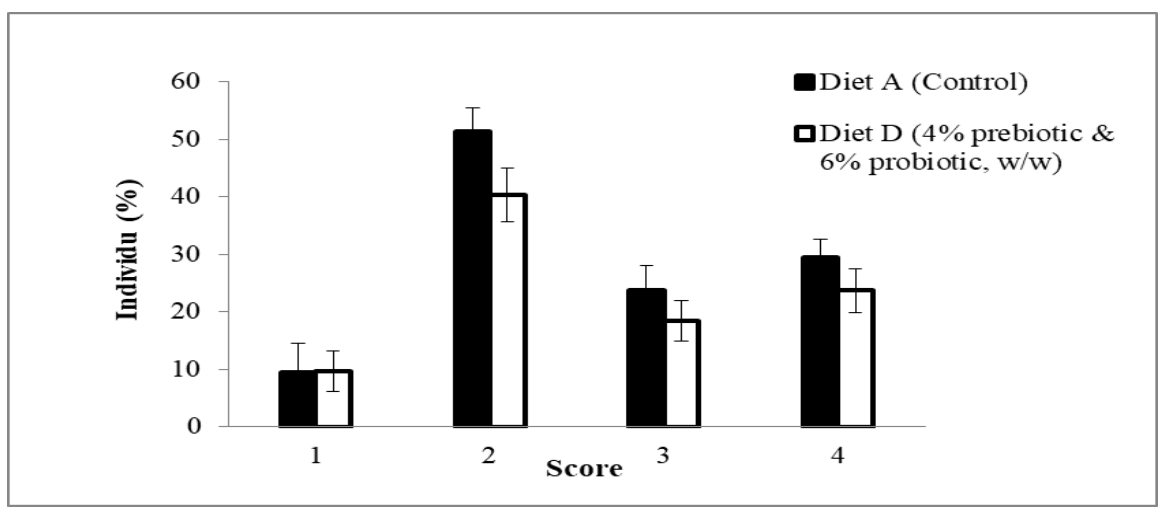

Figure 2. Scoring infection level of shrimps fed on Diet A (Control) and Diet D (4\% prebiotic and 6\% probiotic, w/w) after the challenged test. Data are expressed as Mean \pm SD. Score 1 to 4 indicated light, mild, heavy and very heavy infections, respectively.

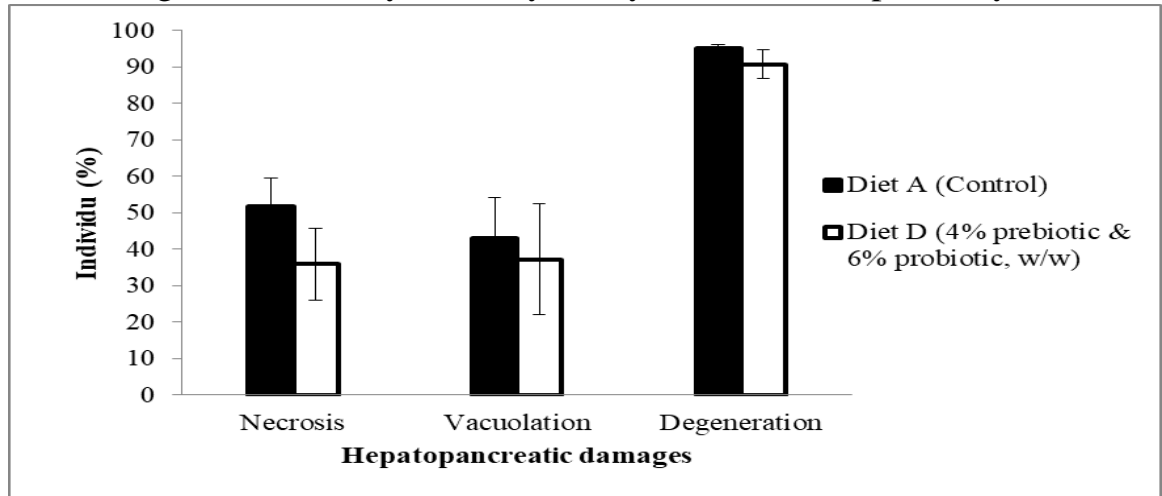

Figure 3. Percentage shrimps suffered from three parameters of hepatopancreatic damages fed on Diet $\mathrm{A}$ (Control) and Diet D (4\% prebiotic and $6 \%$ probiotic, w/w) after seven days challenged test. Data are expressed as Mean \pm SD. 

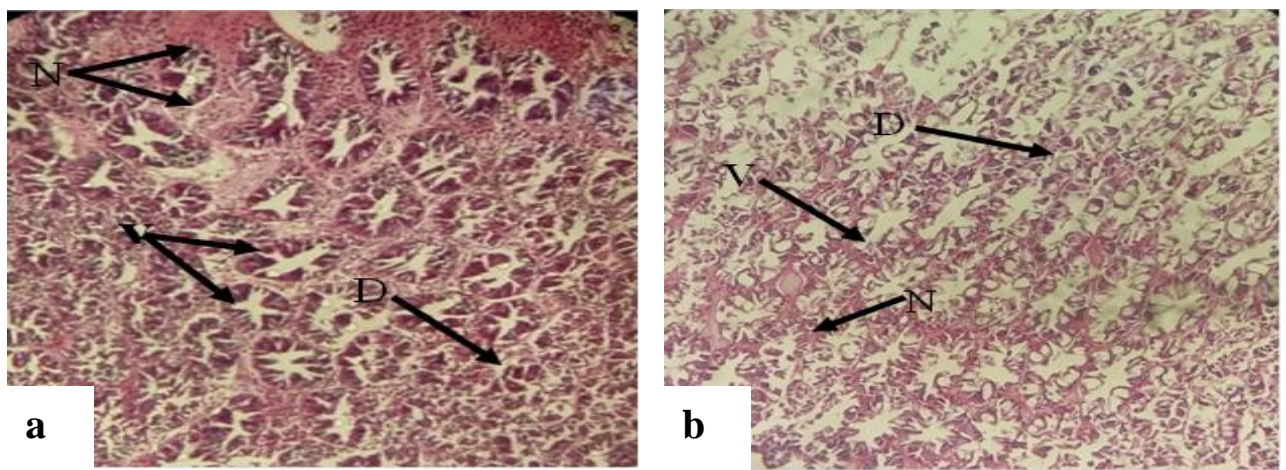

Figure 4. Comparative hepatopancreatic conditions of shrimps fed on Diet A, control (a) and Diet D $4 \%$ prebiotic and $6 \%$ probiotic, w/w $(\mathbf{b})$, histologically. Necrosis $(\mathbf{N})$, vacuolation $(\mathbf{V})$, and degenerative hepatopancreas (D).

\section{Discussion}

The shrimp which were fed with experimental diets containing probiotic and or prebiotic supplements showed better growth performance compared to those in the control group. After 32 days of culture, weight gain and ADG of shrimp has improved while FCR has decreased. The highest growth was measured in the Diet D treatment group. Other research has suggested the similar condition; the dietary administration of synbiotics (application of probiotics together with prebiotics) can influence the growth performance of shrimp (Nurhayati et al., 2015). Administration bacteria such as Bacillus subtilis (Zokaeifar et al., 2012) and Pediococcus pentosaceus (Adel et al., 2017) via dietary supplements in white shrimp may activate the shrimps' digestive enzyme. The improvement in digestive enzyme activities allows the host to digest and absorb more nutrients (Cerezuela et al., 2011). According to $\mathrm{Ai}$ et al. (2011), gastrointestinal bacteria take a part in the decomposition of nutrients, providing the host organism with physiologically active materials such as enzymes, amino acids, and vitamins thus enhance food utilization and digestion. The increase in growth and FCR as a result of dietary supplementation with synbiotics has been credited to physiological and biological changes in the gastrointestinal environment (Daniels et al, 2010).

The changes are suggested to increase absorptive surface area and improve microvilli structure (Dimitroglou et al., 2009). Another study indicates that the application of synbiotics allows for the more efficient conversion of ingested food into structural protein, with subsequent improved growth (Hai and Fotedar, 2009). The Previous study showed that prebiotic extracted from sweet potatoes could support the growth of probiotic bacteria such as Vibrio alginolyticus SKT-b (Nurhayati et al., 2015) and Bacillus sp. D2.2 (Harpeni et al., 2016). In shrimp, Ringo et al. (2010) suggested that prebiotic can selectively support the growth of specific species of bacteria in their digestive tract.

Although survival rate of the shrimp fed with synbiotic supplementation was not significantly increase compared with control diet, this experimental diet (Diet D) could protect the shrimp with RPS value $53.48 \%$. Other research reported RPS values of $L$. vannamei were $45.4-$ $51.9 \%$ while supplemented with probiotics and infected by $V$. harveyi (Liu et al., 2014). Arisa (2011) reported that synbiotic may enhance the resistance of white shrimp to $V$. harveyi. Further study also revealed that combination of probiotic and prebiotic from sweet potato in shrimp diets can significantly improve disease resistance by reducing mortality and stimulating immunity of the shrimp (Nurhayati et al., 2015). Meantime to death of the shrimp fed with Diet D could be longer than those consumed control diet. However, it seems that the Diet D only protect shrimp from bacterial attack. If the shrimp in Diet $\mathrm{D}$ still can be infected by $V$. harveyi, the using of Diet $\mathrm{D}$ will be not significantly different to the development of bacterial infection. Shrimps tend to survive longer in Diet D then those in control indicated that the diet was capable to block the bacterial attack at the beginning. However, the further development of bacterial infection has not been supported by significance of MTD. Therefore, mean time to death of the Die D was not significantly different than of the control diet. Mild infection and mostly degenerative hepatopancreas occurred in shrimp after the challenged test. Diet D has created less damage of hepatopancreas in shrimp. (Figure 3). 
In conclusion, this study showed that probiotic Bacillus sp. D2.2 with prebiotic from sweet potato in pacific white shrimp (Litopenaeus vannamei) diets can significantly improve growth performance and could protect the shrimp from bacterial infection by presumably enhancing immunity and modulating microflora in the digestive tract of shrimp. Based on the result of growth performance (Table 1), longer time of MTD (Figure 1), lower level of infection and less of hepatopancreatic damages (Figure 2 and 3), the best dietary synbiotic in this study was basal diet supplemented with $6 \%$ probiotic and $4 \%$ prebiotic, w/w.

\section{References}

Adel, M., S. Yeganeh, M.A.O. Dawood, R. Safari, and S. Radhakrishnan. 2017. Effects of Pediococcus pentosaceus supplementation on growth performance, intestinal microflora and disease resistance of white shrimp, Litopenaeus vannamei. Aquaculture Nutrition, 23(6): 14011409.

Ai, Q., H. Xu, K. Mai, W. Xu, J. Wang, and W. Zhang. 2011. Effects of dietary supplementation of Bacillus subtilis and fructooligosaccharide on growth performance, survival, non-specific immune response and disease resistance of juvenile large yellow croaker, Larimichthys crocea, Aquaculture, 317:155-161

Arisa, I.I. 2011. Application of probiotic, prebiotic and synbiotic to enhance the immune response of shrimp Litopenaeus vannamei against Vibrio harveyi infection. Master Thesis, Bogor Agricultural University, Indonesia.

Azhar, F. 2013. The effects of probiotic and prebiotic on performance of juvenile polkadot grouper Cromileptes alvelis. Buletin Veteriner Udayana, 6: 1-9.

Bell, T. A. and D.V. Lightner. 1988. A handbook of normal penaeid shrimp histology (No. 595.38 43B4). Word Aquaculture Society, 114p.

Bengmark, S. 2005. Bioecologic control of the gastrointestinal tract: the role of flora and supplemented probiotics and synbiotics. Gastroenterology Clinics of North America, 34:413-436.

Cerezuela, R., F.A. Guardiola, J. Meseguer, and M.A. Esteban. 2012. Increases in immune parameters by inulin and Bacillus subtilis dietary administration to gilthead seabream (Sparus aurata L.) did not correlate with disease resistance to Photobacterium damselae. Fish Shellfish Immunol., 32:1032-1040.

Daniels, C.L., D. L. Merrifield, D.P. Boothroyd, S.J. Davies, J.R. Factor, and K.E. Arnold.
2010. Effect of dietary Bacillus spp. and mannan oligosaccharides (MOS) onEuropean Lobster (Homarus gammarus L.) larvae growth performance, gut morphology and gut microbiota. Aquaculture, 304:49-57.

Dimitroglou, A., D.L Merrifield, R. Moate, S.J. Davies, P. Spring, J. Sweetman, and G. Bradley. 2009. Dietary mannan oligosaccharide supplementation modulates intestinal microbial ecology and improves gut morphology of rainbow trout, Oncorhynchus mykiss (Walbaum). Journal of animal science, 87(10): 3226-3234.

Gibson, G., H. Probert, J. Loo, R. Rastall, and M. Roberfroid. 2004. Dietary modulation of the human colonic microbiota: Updating the concept of prebiotics. Nutrition Research Reviews, 17(2):259-275. doi:10.1079/NRR200479.

Gibson G.R. and M.B. Roberfroid. 1995. Dietary modulation of the human colonic microbiota: introducing the concept of prebiotics. Journal of Nutrition, 125: 1401-1412.

Hai, N.V. and R. Fotedar. 2009. Comparison of the effects of prebiotics (Bio-Mos ${ }^{\circledR}$ and B-1, 3D-glucan) and the customized probiotics (Pseudomonas synxantha and $P$. aeruginosa) on the culture of juvenile western king prawn (Penaeus latisulcatus Kishinouye, 1896). Aquaculture, 289:310-316.

Hardiyani, S., E. Harpeni, A. Setyawan and Supono. 2016. Pathogebicity and in vivo study of local isolate Bacillus sp. D2.2 at the vannamei culture (Litopenaeus vannamei). Aquasains, 5(1): 421-425.

Harpeni, E., A. Setyawan, L. Santoso and Z. Arifin. 2016. Efektivitas ekstrak tepung ubi jalar sebagai media teknis bakteri probiotik. Proceeding Seminar Nasional MIPA 2016: 127- 130. Jatinangor, 27-28 Oktober 2016.

Joshi, J., J. Srisala, V.H. Truong, I.T. Chen, B. Nuangsaeng, O. Suthienkul, C.F. Lo, T.W. Flegel, K. Sritunyalucksana, and S. Thitamadee. 2014. Variation in Vibrio parahaemolyticus isolates from a single Thai shrimp farm experiencing an outbreak of acute hepatopancreatic necrosis disease (AHPND). Aquaculture, 428: 297-302.

Khimmakthong, U., P. Deachamag, A. Phongdara, and W. Chotigeat. 2011. Stimulating the immune response of using the phagocytosis activating protein (PAP) gene, Fish \& Shellfish Immunology, 31(3): 415-422.

Li J.Q., B.P. Tan and K.S. Mai. 2009. Dietary probiotic Bacillus OJ and isomaltooligo saccharides influence the intestine microbial populations, immune responses and resistance to white spot syndrome virus in shrimp (Litopenaeus vannamei). Aquaculture. 291: 35-40.

Li P., G.S. Burr, D.M III. Gatlin, M.E. Hume, S. Patnaik, F.L. Castille, and A.L. Lawrence. 2007. Dietary supplementation of short-chain 
fructooligosaccharides influences gastrointestinal microbiota composition and immunity characteristics of Pacific white shrimp, Litopenaeus vannamei, cultured in a recirculating system. Journal of Nutrition, 137: 2763-2768

Liu, H., Z. Li, B. Tan, Y. Lao, Z. Duan, W. Sun, and $\mathbf{X}$. Dong. 2014. Isolation of a putative probiotic strain $\mathrm{S} 12$ and its effect on growth performance, non-specific immunity and disease-resistance of white shrimp, Litopenaeus vannamei. Fish \& shellfish immunology, 41(2): 300-307.

Nitimulyo, K.H., A. Isnansetyo, Triyanto, M. Murdjani, and L. Sholichah. 2005. Efektivitas vaksin polivalen untuk pengendalian vibriosis pada kerapu tikus (Cromileptes altivelis). J. Fish. Sci., 7(2): 95-100.

Nurhayati, D., Widanarni, and M. Yuhana. 2015. Dietary symbiotic influence on growth performances and immune responses to coinfection with infectious myonecrosis virus and Vibrio harveyi in Litopenaeus vannamei. Journal of Fisheries and Aquatic Science, 10(1): 13-23.

Oktaviana, A., Widanarni and Yuhana, M. 2014. The Use of Synbiotics to Prevent IMNV and Vibrio harveyi Co-Infection in Litopenaeus vannamei. HAYATI Journal of Biosciences, 21(3): 127-134.

Partida-Aranguere, B.O., A. Luna-Gonzalez, J.A. Fierro-Coronado, M. del-Carmen FloresMiranda, and H.A. Gonzalez-Ocampo. 2013. Effect of inulin and probiotic bacteria on growth, survival, immune response, and prevalence of white spot syndrome virus (WSSV) in Litopenaeus vannamei cultured under laboratory conditions. Afr. J. Biotechnol., 12: 3366-3375.

Rengpipat, S., W. Phianphak, S. Piyatiratitivorakul, and P. Menasveta. 1998. Effects of a probiotic bacterium on black tiger shrimp (Penaeus vannamei) survival and growth. Aquaculture, 167: 301-313.

Rengpipat, S., S. Rukpratanporn, S. Piyatiratitivorakul, and $P$. Menasveta. 2000. Immunity enhancement in black tiger shrimp (Penaeus vannamei) by a probiont bacterium Bacillus S11. Aquaculture, 191: 271-288.

Rengpipat, S., A. Tunyamum, A.W. Fast, S. Piyatiratitivoraku, and $P$. Menasveta. 2003. Enhanced growth and resistance to vibrio challenge in pond-reared black tiger shrimp Penaeus monodon fed a Bacillus probiotic. Diseases of Aquatic Organisms 55. 169-173.

Ringo, E., R.E. Olsen, T.O. Gifstad, R.A. Dalmo, H. Amlund, G.I. Hemre, and A.M. Bakke. 2010. Prebiotics in aquaculture: A review. Aquacult. Nutr., 16: 117-136.
Setyawan, A., E. Harpeni, M. Ali, D. Mariska, and M. Aji. 2014. Potensi agen bakteri biokontrol indigenous tambak tradisional udang windu (Penaeus monodon) di Lampung Timur strain D.2.2, terhadap bakteri patogen pada udang dan ikan. Prosiding Pertemuan Ahli Kesehatan Ikan 2014. Serang 11-13 Februari 2014. pp. 24-31.

Soccol, C.R., L.P.d.S. Vandenberghe, M.R. Spier, A.B.P. Medeiros, C.T. Yamaguishi, J.D.D. Lindner, A. Pandey, and V. Thomaz-Soccol. 2010. The potential of probiotics: a review. Food Technology and Biotechnology, 48(4):413-434.

Sukenda, R. Praseto, and Widanarni. 2015. Efektivitas sinbiotik dengan dosis berbeda pada pemeliharaan udang vaname di tambak. Jurnal Akuakultur Indonesia, 14(1): 1-8.

Sun, Y., Wen, Z., Li, X., Meng, N., Mi, R., Li, Y. and Li, S. 2012. Dietary supplement of fructooligosaccharides and Bacillus subtilis enhances the growth rate and disease resistance of the sea cucumber Apostichopus japonicus (Selenka). Aquac. Res., 43:13281334. doi:10.1111/j.1365-2109.2011.02936.x

U.S. Food and Drug Administration. 2008. Fish and Fishery Products Hazards and Controls Guidance Department of Health and Human Services, Food and Drug Administration, Center for Food Safety and Applied Nutrition Medicine.http://www.fda.gov/downloads/foo d/guidanceregulation/ucm251970.pdf.

Verschuere, L., G. Rombaut, P. Sorgeloos, and W. Verstraete. 2000. Probiotic Bacteria as Biological Control Agents in Aquaculture. Microbiology and Molecular Biology, 64(4): 655-671.

Wright, G. D. 2010. Antibiotic resistance in the environment: a link to the clinic. Current Opinion in Microbiology, 13(5): 589-594.

Xiong, J., K. Wang, J. Wu, L. Qiuqian, K. Yang, Y. Qian, and D. Zhang. 2015. Changes in intestinal bacterial communities are closely associated with shrimp disease severity. Applied microbiology and biotechnology, 99(16): 6911-6919.

Zhou Z., Z. Ding and H.Y. Lv. 2007. Effects of dietary short-chain fructooligosaccharides on intestinal microflora, survival and growth performance of juvenile Pacific white shrimp Litopenaeus vannamei. Journal of the World Aquaculture Society, 38: 296-301.

Zokaeifar, H., Balcázar, J. L., Saad, C. R., Kamarudin, M. S., Sijam, K., Arshad, A., and Nejat, N. 2012. Effects of Bacillus subtilis on the growth performance, digestive enzymes, immune gene expression and disease resistance of white shrimp, Litopenaeus vannamei.Fish \& shellfish immunology, 33(4): 683-689. 